\title{
VÝHODY MODELOVÁNÍ SVOZU KOMUNÁLNÍHO ODPADU V PROSTŘEDÍ GIS
}

\author{
Lucie ORLÍKOVÁ ${ }^{1}$, Petr KOZEL ${ }^{2}$ \\ ${ }^{1}$ Katedra geoinformatiky, Hornicko-geologická fakulta, VŠB-TU Ostrava, 17.listopadu 15, 708 00, Ostrava, \\ Česká republika \\ lucie.orlikova@vsb.cz \\ ${ }^{2}$ Katedra ekonomických metod v matematice, Ekonomická fakulta, , VŠB-TU Ostrava, 17.listopadu 15, 708 \\ 00, Ostrava, Česká republika \\ petr.kozel@vsb.cz
}

doi: https://doi.org/10.31490/9788024845081-123

\begin{abstract}
Abstrakt
Právní předpisy EU i na národní úrovni České republiky v oblasti nakládání s komunálními odpady kladou na poskytovatele těchto služeb, zejména na obce a jejich sdružení, stále větší požadavky, především požadují vysokou míru využitelnosti a recyklace u široké škály materiálů a zboží. Tento príspěvek se zabývá modelováním a optimalizací tras komunálního odpadu v oblasti malých obcí na Třinecku. $\mathrm{K}$ dispozici byly údaje o adresách jednotlivých obslužných míst, jejich kapacita a požadavky na četnost svozu. Jednotlivá odběrná místa musela být geokódována, na základě sumárních výpočtů a s ohledem na celkovou hmotnost a kapacitu obslužného vozidla byl stanoven počet svozů. K dekompozici byl využit dvoukrokový dekompoziční přístup založený na p-medián př́istupu a trasy byly následně optimalizovány. Výsledné trasy byly následně otestovány pomocí obslužných vozidel Nehlsen Třinec, s.r.o.
\end{abstract}

\section{Abstract}

The European Union and national waste management policies and legislation in the Czech Republic are becoming increasingly demanding for the providers of these services, namely municipalities and their associations, demanding high recovery and recycling rates for a wide range of materials and goods. This paper deals with modeling and optimization of waste collection routes in Trinec region. The addresses of individual service points, their capacity and requirements for the frequency of collection were available. These individual service points were geocoded, the number of pick-ups was determined on the basis of summary calculations and with regard to the total weight and capacity of the service vehicle. A two-step decomposition approach based on the p-median was used for the decomposition and the routes were subsequently optimized. The routes were subsequently tested using Nehlsen Třinec, s.r.o. service vehicles.

Klíčová slova: geokódování, nakládání s odpady, hledání optimální trasy, GIS.

Keywords: geocoding, waste management, route planning, GIS

\section{ÚVOD}

Svozem komunálního odpadu se $v$ posledních dekádách zabývá nepřeberné množství autorů z různých částí světa. I přesto byly některé ze studií unikátní a zaměřovaly se na rưzné faktory typické pro území, pro které byly tvořeny.

Nuortio et al. (2006) ve své studii popisuje plánování tras pro svoz komunálního odpadu ve dvou odlišných regionech ve východním Finsku. $V$ minulosti se toto plánování provádělo manuálně. Ve studovaném území se nachází zhruba 30 tis. kontejnerů několika typů, každé vozidlo jich za jeden den typicky sveze několik stovek. Svoz je prováděn výhradně během pracovních dní. Na konci směny je vozidlo, za předpokladu, že je naplněno alespoň z poloviny, vyprázdněno. Počíá se s osmihodinovou pracovní dobou, která je rozdělena půlhodinovou pauzou na oběd. To znamená, že $v$ jednom dni mohou být vykonány dvě různé trasy. Ve své práci Nuortio et al. (2006) pracuje s Dijkstrovým algoritmem (Dijkstra, 1959), který nalézá nejkratší trasu z 
výchozího bodu do všech ostatních uzlů $v$ definované síti. Data o čase nakládky a přejezdu po hranách vychází z regresní analýzy historických dat.

Perpiñá et al. (2009) se zabýval alternativním řešením optimalizace, kterým může být analýza použitá při určení optimálního umístění spalování biomasy. Vybrané území bylo prvně rozděleno na čtverce o velikosti 1 $\mathrm{km}^{2}$. Centroid každého čtverce byl ohodnocen a klasifikován jako počátek nebo cíl. Následně byla vypočitána produkce biomasy $v$ jednotlivých čtvercích za jeden rok. Pomocí ArcGIS a nástroje OD Cost Matrix, která je součástí nadstavby Network Analyst, byla vypočítána vzdálenost do místa prípadného umístění elektrárny. Poté byly za pomocí nástroje Closes Facility nalezeny sběrné oblasti biomasy. Tato metoda však nezohledňuje topologické vztahy, je tudíž pro úlohu svozu odpadu méně vhodná.

Ve výše uvedených studií byly vytvořené modely aplikované na relativně malé oblasti tzn., že tyto modely nemusí být obecně platné. $V$ tomto ohledu se vymyká studie od Zamorano et al. (2008). Vytvoriil komplexní model, který je aplikovatelný na více typů měst. Rozdělil města do kategorií dle velikosti, jelikož počet obyvatel $v$ dané oblasti má citelný vliv na jejich chování $v$ samotné produkci odpadu. Tímto docílil $v$ porovnání s dosavadními trasami redukce celkové ujeté vzdálenosti o téměř $41 \%$. Počet kontejnerů, které byly obslouženy každý den, se snížil o 38 \%. Odlišně zpracovaný model vytvořil Tavares et al. (2008), který je vhodný pro členitější území s horší dostupností

Ačkoliv je samotný svoz odpadu jedním z největších výdajů firem zabývajících se tímto odvětvím, spousta z nich tuto problematiku zanedbává a nevěnuje jí prŕlišnou pozornost. Náklady na svoz nejsou zdaleka ovlivněny pouze počtem a servisem vozidel či počtem zaměstnanců, ale především efektivitou svozu - tedy za co nejmenší náklady obsloužit co nejvíce zákazníků a svézt jejich odpad. Všechny tyto skutečnosti je zároveň nutné zkoumat i z hlediska ekologického. Důležitost této problematiky dokládá i rostoucí trend produkce odpadu.

\section{METODIKA A VÝSLEDKY}

Plánování tras obslužných vozidel je nedílnou součástí rozhodovacího procesu všech subjektů poskytujících služby v oblasti komunálního odpadu.

K dispozici byly údaje o adresách jednotlivých obslužných míst, jejich kapacita a požadavky na četnost svozu. Jednotlivá odběrná místa musela být geokódována, na základě sumárních výpočtů a $\mathrm{s}$ ohledem na celkovou hmotnost a kapacitu obslužného vozidla byl stanoven počet svozů. Geokódování adres bylo testováno prostřednictvím nástroje Geocode by Awesome Table a knihovny OpenCage Geocoder. GeoCode by Awesome Tables je softwarová komponenta integrovatelná do prostředí Google, využitelná pro množství úkonů. Jedinou podmínkou je vlastnit Google účet, v takovém případě Ize GeoCode používat jako doplněk pro Tabulky Google. Ve druhé metodě, bylo na rozdíl od první, využito programovacího jazyka, konkrétně Python. Po vyzkoušení několika různých možností, jak geokódovat pomocí jazyka Python, se jeví nejlépe knihovna OpenCage Geocoder. Po registraci, která je zdarma, je k dispozici API-KEY, na kterém je možno provést až 2500 požadavků za den. Obě metody byly po provedení porovnány s adresními body z registru územní identifikace a na základě tohoto porovnání byla vytvořena statistika úspěšnosti metod.

Při zpracovávání úloh, jež jsou zaměřeny na obsluhu vrcholů dopravní sítě, je nutné dbát nejen na optimální pořadí vrcholů za současného zachování zvoleného optimalizačního kritéria (např. celkovou ujetou vzdálenost), ale také ostatní omezení, která vyplývají z potřeb praxe. Jedním z nejčastějších omezení při tvorbě tras obslužných vozidel, které vstupuje do rozhodovacího procesu, je kapacita. Při návrhu optimální trasy obslužného vozidla je nejčastěji hledáno pořadí vrcholů začínající a končící v depu, kdy trasa zároveň prochází všemi požadovanými vrcholy sítě, u kterých je požadována obsluha, a které mají minimální délku. Zároveň je vyžadována podmínka, aby kapacita vozidla nebyla překročena. Jestliže je splněna podmínka, že součet požadavků situovaných $v$ jednotlivých uzlech sítě nebude větší než kapacita obslužného vozidla, je možné pro navrhnutí trasy vyjít $z$ úlohy o vyhledání minimální Hamiltonovy kružnice. $V$ tomto prípadě je pak výslednou trasou obslužného vozidla jedna okružní jízda začínající a končící $v$ depu. $V$ případě, že není splněn požadavek na nepřekročení kapacity vozidla, je potřeba přistoupit $k$ některému $z$ náhradních 
přístupů. Mezi dva základní přístupy patří metoda primárního shlukování, označovaná jako Cluster-First Route-Second a metoda primárního trasování, označovaná jako Route-First Cluster-Second (Kozel, 2017).

K dekompozici byl využit dvoukrokový dekompoziční přístup založený na p-medián přístupu a trasy byly následně optimalizovány pro jednotlivé obce v oblasti Třinecka. Využití p-medián přistupu ukázalo úsporu $\checkmark$ celkové délce navržených tras $v$ rozsahu od $4.3-12.5 \%$.

\section{LITERATURA}

Kozel P., Dekompozice okružních jízd s využitím matematického programování, [online]. 2017, XII(3). Perner's Contacts, 12(3), 62-70.

Nuortio T., Kytöjoki J., Niska H., Bräysy O., Improved route planning and scheduling of waste collection and transport, Expert Systems with Applications, Volume 30, Issue 2, 2006, Pages 223-232, ISSN 0957-4174, https://doi.org/10.1016/j.eswa.2005.07.009.

Perpiñá C., Alfonso D., Pérez-Navarro A., Peñalvo E., Vargas C., Cárdenas R., Methodology based on Geographic Information Systems for biomass logistics and transport optimisation, Renewable Energy, Volume 34, Issue 3, 2009, Pages 555-565, ISSN 0960-1481, https://doi.org/10.1016/j.renene.2008.05.047.

Tavares G., Zsigraiova Z., Semiao V., Carvalho M.G., Optimisation of MSW collection routes for minimum fuel consumption using 3D GIS modelling, Waste Management, Volume 29, Issue 3, 2009, Pages 11761185, ISSN 0956-053X, https://doi.org/10.1016/..wasman.2008.07.013.

Zamorano M., Molero E., Grindlay A., Rodríguez M.L., Hurtado A, Calvo F.J., A planning scenario for the application of geographical information systems in municipal waste collection: A case of Churriana de la Vega (Granada, Spain), Resources, Conservation and Recycling, Volume 54, Issue 2, 2009, Pages 123-133, ISSN 0921-3449, https://doi.org/10.1016/j.resconrec.2009.07.001. 